Table 2. Taste thresholds in short stature as a variant of normal

\begin{tabular}{ccccc}
\hline Patient & $\mathrm{NaCl}$ & Sucrose & Urea & $\mathrm{HCl}$ \\
\hline 1 & $30 / 30$ & $15 / 30$ & $150 / 150$ & $6 / 30$ \\
2 & $30 / 30$ & $15 / 15$ & $120 / 120$ & $6 / 6$ \\
3 & $30 / 30$ & $15 / 60$ & $120 / 150$ & $6 / 6$ \\
4 & $30 / 30$ & $15 / 30$ & $120 / 120$ & $3 / 3$ \\
5 & $30 / 30$ & $15 / 15$ & $120 / 150$ & $3 / 6$ \\
6 & $30 / 30$ & $15 / 15$ & $120 / 120$ & $6 / 30$ \\
7 & $30 / 30$ & $15 / 15$ & $120 / 120$ & $3 / 3$ \\
8 & $30 / 60$ & $15 / 30$ & $120 / 120$ & $6 / 30$ \\
9 & $30 / 30$ & $15 / 15$ & $120 / 120$ & $3 / 3$ \\
10 & $60 / 60$ & $15 / 15$ & $150 / 150$ & $30 / 60$ \\
11 & $30 / 30$ & $15 / 15$ & $120 / 150$ & $3 / 30$ \\
12 & $30 / 30$ & $15 / 30$ & $120 / 120$ & $3 / 15$ \\
\hline
\end{tabular}

Copyright @ 1976 International Pediatric Research Foundation, Inc.
Table 3. Taste thresholds in juvenile Crohn's disease

\begin{tabular}{ccccc}
\hline Patient & $\mathrm{NaCl}$ & Sucrose & Urea & $\mathrm{HCl}$ \\
\hline$I$ & $150 / 150$ & $30 / 30$ & $500 / 1,000$ & $\mathrm{ND}^{\prime} \mathrm{NR}^{1}$ \\
2 & $90 / 90$ & $15 / 30$ & $150 / 150$ & $6 / 6$ \\
3 & $30 / 60$ & $15 / 30$ & $150 / 150$ & $6 / \mathrm{NR}$ \\
4 & $30 / 60$ & $15 / 15$ & $120 / 150$ & $3 / 3$ \\
5 & $60 / 90$ & $60 / 150$ & $150 / 300$ & $60 / 60$ \\
\hline
\end{tabular}

${ }^{1}$ ND: not detected; NR: not recognized.
Atherosclerosis

cholesteryl ester storage disease lysosomal acid lipase

\title{
Genetic Variation of Lysosomal Acid Lipase
}

\author{
J. A. CORTNER, ${ }^{(50)}$ P. M. COATES, E. SWOBODA, AND J. D. SCHNATZ \\ Departments of Pediatrics and Medicine, State University of New York at Buffalo and Children's Hospital of \\ Buffalo, Buffalo, New York; Department of Pediatrics, University of Pennsylvania and Children's Hospital of Philadelphia. \\ Philadelphia, Pennsylvania, USA
}

\section{Extract}

Lysosomal acid lipase (LAL) activity was measured using a new fluorometric assay in cultured skin fibroblasts from eight control subjects, two obligate heterozygotes for Wolman's disease (WD), one patient with WD, and one patient with cholesteryl ester storage disease (CESD). The LAL activities (mean $\pm \mathrm{SD}$ ) were $25.8 \pm 8.2$, $13.2 \pm 0.1,1.1$, and $1.4 \mathrm{nmol}$ 4-methylumbelliferyl oleate (4-MUO) hydrolyzed $/ \mathrm{min} / \mathrm{mg}$ protein, respectively. These results compare favorably with those obtained using standard radioassays. The LAL activities of two cultures of amniotic fluid cells were 12.1 and 10.5. The LAL activity (mean \pm SD) of peripheral leukocytes obtained from 34 laboratory volunteers ( 19 females, 15 males) was $4.0 \pm 1.8$. Partially purified lymphocytes contained about 25 times as much LAL activity as did granulocytes. Cellogel electrophoresis, followed by staining with 4-MUO, showed at least two bands of LAL ( $A$ and B) from normal fibroblasts, amniotic fluid cells, and lymphocytes. Band A was absent from WD and CESD fibroblasts and was reduced in fibroblasts of the WD heterozygotes.

\section{Speculation}

Deficiency of lysosomal acid lipase activity is associated with lysosomal accumulation of cholesteryl esters and triglycerides. One of the early events in atherogenesis is the accumulation of cholesteryl esters in the lysosomes of arterial smooth muscle cells. Genetic variants of lysosomal acid lipase, resulting in reduced activity or altered catalytic properties, may be predisposing factors in the development of premature atherosclerosis.
Deficiency of lysosomal acid lipase (LAL) (33) is associated with a wide spectrum of clinical disease in man, ranging from the fatal infantile form of Wolman's disease (WD) to the relatively benign disorder, cholesteryl ester storage disease (CESD). There have been some 35 cases of WD, its clinical variants, and CESD reported in the literature since $1956(19,25)$. Table 1 summarizes the cases from 1971 to the present. Deficiency of LAL in these diseases results in massive lysosomal accumulation of neutral fats, chiefly cholesteryl esters and triglycerides, in the cells of a variety of tissues (9). The acute infantile form of WD is usually fatal within 6 months of life. Variants of WD with later onset and longer survival have been reported (19). Other variants of WD, as well as CESD, are apparently clinically benign conditions. The reported patients are still alive, with the exception of female twins (10) who died of unrelated causes.

In this report, we present an additional case of WD with details of procedures for the quantitative assay and electrophoresis of LAL in fibroblasts of this patient, her parents, and a patient with CESD.

\section{CASE REPORT}

$A J$ was an apparently normal newborn girl delivered uneventfully to a healthy gravida 1 , para 0,20 -year-old Caucasian woman and her 26-year-old unrelated Caucasian husband. The family history was unremarkable. The patient was well until 8 weeks of age when abdominal distention was noted. She continued to appear alert and well except for increasing abdominal distention until her first hospital admission (October 28, 1971) at 10 weeks of age. On 
Table 1. Recent cases (1971-present) of Wolman's disease (WD) and cholesteryl ester storage disease $(D E S D)^{1}$

\begin{tabular}{|c|c|c|c|c|c|c|}
\hline Case & Sex & Onset & Death & Diagnosis & Consanguinity, siblings & Reference \\
\hline$l$ & $F$ & $5 w$ & $9 w$ & WD & $I$ affected $M$ sib & 15 \\
\hline 2 & $\mathbf{M}$ & $\mathrm{Im}$ & $2.5 \mathrm{~m}$ & WD & Parents related & 29 \\
\hline 3 & M & $10 \mathrm{~d}$ & $3.5 \mathrm{~m}$ & WD & $\begin{array}{l}\text { Parents related; } 3 \text { affected, } \\
4 \text { normal sibs }\end{array}$ & 22 \\
\hline 4 & $\mathbf{M}$ & $38 \mathrm{~d}$ & $45 \mathrm{~d}$ & WD & 1 affected sib & 22 \\
\hline 5 & $\mathbf{F}$ & $\mathrm{Im}$ & $2.5 \mathrm{~m}$ & WD & 3 normal sibs & 12 \\
\hline 6 & $\mathbf{F}$ & $3 \mathrm{~m}$ & $4 m$ & WD & $\begin{array}{l}\text { Parents related, } 1 \text { affected } \\
\text { F, } 4 \text { normal } \mathrm{M} \text { sibs }\end{array}$ & 14 \\
\hline 7 & $\mathbf{F}$ & $8 w$ & $19 w$ & WD & 1 normal $M$ sib & 6 and present report \\
\hline 8 & $\mathbf{F}$ & $?$ & Alive & CESD & $\begin{array}{l}2 \text { deceased } F \text { sibs similarly } \\
\text { affected, } 2 \text { normal } M \text { sibs }\end{array}$ & 2 \\
\hline 9 & $\mathbf{F}$ & $7 y$ & $\begin{array}{l}\text { Alive } \\
\text { at } 17 y\end{array}$ & CESD & $\begin{array}{l}1 \text { affected } F, 2 \text { normal } M \\
\text { sibs }\end{array}$ & 31 \\
\hline
\end{tabular}

${ }^{1} \mathrm{~F}$ : female; M: male; d: days; w: weeks; m: months; y: years.

physical examination, her height was at the 50th percentile, her weight and head circumference at the 8th percentile. Abdominal distention was in part due to the presence of ascites and there was enlargement of the liver, palpable $6 \mathrm{~cm}$ below the right costal margin, and the spleen, $4 \mathrm{~cm}$ below the left.

Serum cholesterol ranged from $123-171 \mathrm{mg} / 100 \mathrm{ml}$ and serum triglycerides ranged from $148-232 \mathrm{mg} / 100 \mathrm{ml}$. Lipoprotein electrophoresis showed $5 \% \alpha-, 21 \%$ pre- $\beta$-, and $74 \% \beta$-lipoprotein. Initial liver function studies were normal. Serum cortisol was in the normal range.

$\mathrm{X}$-ray (flat plate) studies and intravenous pyelography revealed massive bilateral adrenal calcification. Vacuoles were observed in peripheral blood lymphocytes and bone marrow. The findings suggested Wolman's disease. The child's condition progressively deteriorated over the next 2 months; she developed severe anemia, thrombocytopenia, progressive hepatosplenomegaly, generalized edema, and jaundice. She died at 19 weeks of age in cardiorespiratory arrest.

\section{PATHOLOGIC REPORT}

The body was that of a 4-month-old female, weighing 5,222 gm and measuring $60 \mathrm{~cm}$ in crown-heel length. There was generalized edema, abdominal distention, and jaundice. Fifty milliliters of ascitic fluid were present. Minimal left ventricular hypertrophy was present. The liver was massively enlarged $(528 \mathrm{~g} ; 160 \mathrm{~g}$ normal), bright yellow, and firm. The spleen was also massively enlarged ( $267 \mathrm{~g} ; 16 \mathrm{~g}$ normal), and of normal color. Lymph nodes throughout the body were enlarged, bright yellow, and firm. The adrenals were symmetrically enlarged (right $15 \mathrm{~g}$, left $19 \mathrm{~g}$; normal combined weight $15 \mathrm{~g}$ ), very firm, and bright yellow. Calcifications were observed on the cut surfaces in the deep cortical areas. The kidneys were somewhat enlarged symmetrically (61 g; $53 \mathrm{~g}$ normal). Yellowish mottling of the cortex and the papillae was observed. The costochondral junctions were yellowish and the spinal ganglia were enlarged and yellowish.

On microscopic examination, "foam" cells were found in the pulmonary alveoli and interstitium, the duodenal mucosa, the mesenteric adipose tissue, throughout the liver, and within the thymus, spleen, lymph nodes, bone marrow, and adrenals. The liver showed fine fibrosis and focal canalicular bile stasis. The peripheral fetal cortex of both adrenals was calcified.

Frozen sections of formalin-fixed tissue revealed abundant Oil Red O-positive material in the foam cells of all tissues, and also in cells not recognizably "foamy," including bronchial cartilage and epithelium, arterial walls, hepatic parenchyma and biliary epithelium, macrophages and/or round cells in the gut and kidney, and throughout the adrenal cortex.

Lipid analysis of liver and spleen (by Drs. D. S. Fredrickson and
H. R. Sloan at National Institutes of Health) revealed; liver triglycerides $42.1 \mathrm{mg} / \mathrm{g}$ wet weight (normal $=19.4 \pm 5.2$ ), cholesteryl esters $24.3 \mathrm{mg} / \mathrm{g}$ (normal $=1.0 \pm 0.3$ ), free cholesterol $9.8 \mathrm{mg} / \mathrm{g}$ (normal $=1.5 \pm 0.4$ ); spleen triglycerides 3.0 (normal $<0.5$ ), cholesteryl esters 3.4 (normal $=0.5 \pm 0.2$ ), and free cholesterol 0.3 (normal <0.5) (1).

Drs. Fredrickson and Sloan also assayed liver acid triglyceride lipase (ATGL) and acid cholesteryl ester hydrolase (ACEH). These were $570 \mathrm{pmol} / \mathrm{hr} / \mathrm{mg}$ tissue at $\mathrm{pH} 4.0$ (normal $=5,750 \pm$ 3,600 ) for ATGL and $0.44 \mathrm{pmol} / \mathrm{hr} / \mathrm{mg}$ tissue at $\mathrm{pH} 4.0$ (normal = $107 \pm 23$ ) for $\mathrm{ACEH}$.

\section{MATERIALS AND METHODS}

\section{FIBROBLAST CULTURES}

Skin biopsies were obtained from the patient at 11 weeks of age and from both her parents using an electric rotating punch drill. Cultured fibroblast cells from a patient with cholesteryl ester storage disease ( $L M c$, References 10 and 26) were obtained from Dr. H. R. Sloan.

Skin biopsies from five infants (four male, one female) and three adults (two male, one female), all apparently healthy, were obtained as controls. Amniotic fluid cells were cultured from two fetuses. All cells were grown in Ham's F10 medium supplemented with $15 \%$ fetal calf serum (34).

Cultures were maintained in roller bottles $\left(490 \mathrm{~cm}^{2}\right.$ growth area, Reference 35 ) and fed regularly twice weekly. All cells used in enzymatic assays, electrophoresis, and Oil Red $\mathrm{O}$ staining were derived from the 5 th to 12 th subcultures, harvested early after confluence.

\section{OIL RED O STAINING}

Fibroblasts were grown on cover slips in Leighton tubes. After a monolayer developed, the medium was removed, the cells were washed in normal saline, and fixed in $10 \%$ formalin. After $10 \mathrm{~min}$ in $50 \%$ pyridine, slides were stained for $30 \mathrm{~min}$ in $4 \%$ Oil Red O in $70 \%$ pyridine, destained for $3-5 \mathrm{~min}$ in $50 \%$ pyridine, and counterstained for $90 \mathrm{sec}$ in aqueous hematoxylin.

\section{PREPARATION OF FIBROBLASTS FOR ENZYME ASSAY AND ELECTROPHORESIS}

Cells grown in roller bottles were harvested by trypsinization, washed three times in normal saline, and suspended in 5-10 volumes of distilled water. They were sonicated in an ice bath for $30 \mathrm{sec}$ at $30 \mathrm{~W}$ with a Branson Sonifier (36) and centrifuged at $40,000 \times g$ for $30 \mathrm{~min}$ at $4^{\circ}$. The supernatant was stored at $-65^{\circ}$ until assayed. 

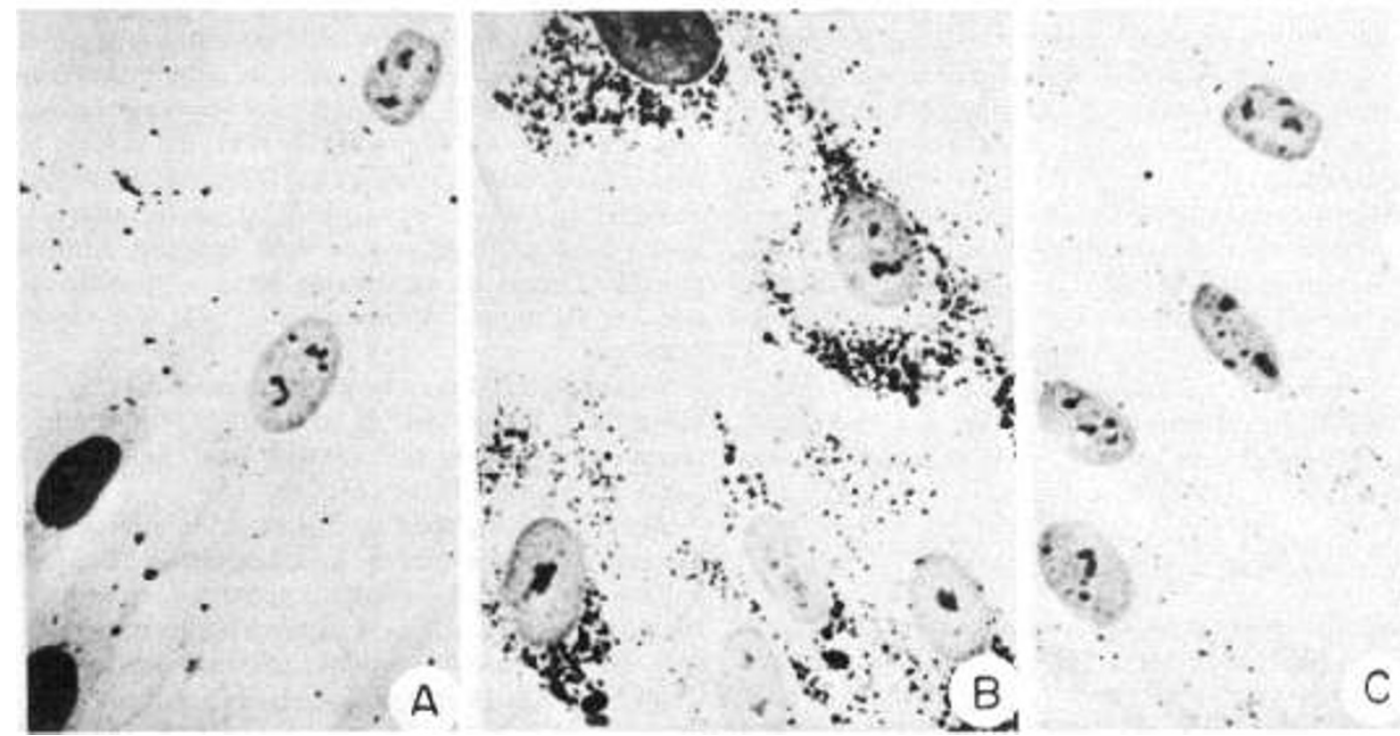

Fig. 1. Oil Red $O$ staining of cultured fibroblasts. $A$ : normal; $B$ : Wolman's disease: $C$ : heterozygote. Magnification $\times 900$.

Table 2. Lysosomal acid lipase specific activities in fibroblasts ${ }^{1}$

\begin{tabular}{lccc}
\hline & \multicolumn{3}{c}{ Substrate } \\
\cline { 2 - 4 } \multicolumn{1}{c}{ Subject $(n)$} & 4-MUO & {$\left[{ }^{14} \mathrm{C}\right]$ Triolein } & $\begin{array}{c}\left.{ }^{14} \mathrm{C}\right] \text { Cholesteryl } \\
\text { oleate }\end{array}$ \\
\hline Control $(8)$ & $25.8 \pm 8.2^{2}$ & $36.5 \pm 4.6^{3}$ & $138.1 \pm 53.9^{3}$ \\
Heterozygote & $13.1,13.3$ & $18.3,12.3$ & Not tested \\
WD (1) & 1.1 & 0.1 & 10.1 \\
CESD (1) & 1.4 & 0.1 & 14.0 \\
\hline
\end{tabular}

${ }^{1}$ Results are shown as mean \pm SD. 4-MUO: 4-methylumbelliferyl oleate.

${ }^{2}$ Nanomoles of substrate hydrolyzed per min per mg protein.

${ }^{3}$ Picomoles of free fatty acid liberated per hr per mg protein.

\section{PREPARATION OF LEUKOCYTES}

Peripheral leukocytes were obtained from fresh, heparinized venous blood, either as buffy coat preparations or after dextran sedimentation (3). Purified lymphocytes and granulocytes were obtained by centrifugation in Lymphoprep (37) by the method of Böyum (4). Cell pellets were freed of erythrocytes by hypotonic lysis, and then sonicated and centrifuged as described above for fibroblasts.

\section{ASSAY OF LYSOSOMAL ACID LIPASE ACTIVITY}

Fluorometric Assay. One milliliter of $10^{-2} \mathrm{M} 4$-methylumbelliferyl oleate (4-MUO, Reference 38) in hexane and one $\mathrm{ml}$ of 16 mM L- $\alpha$-phosphatidylcholine (egg yolk lecithin, Reference 39 ) in hexane were evaporated together to dryness under a stream of nitrogen, resuspended in $25 \mathrm{ml}$ of $2.4 \mathrm{mM}$ sodium taurocholate (40) and sonicated (36) in an ice bath at $50 \mathrm{~W}$ for $1 \mathrm{~min}$. The substrate appeared to be a very fine homogeneous dispersion, and was stable for periods up to 4 days. At the time of assay, 1 volume was added to 7 volumes of $0.2 \mathrm{M}$ acetate buffer, $\mathrm{pH} 4.0$. Each $2.0-\mathrm{ml}$ reaction vessel contained $0.1 \mu \mathrm{mol} 4-\mathrm{MUO}, 0.16 \mu \mathrm{mol}$ lecithin, and $0.6 \mu \mathrm{mol}$ sodium taurocholate. Enzyme source (5-50 $\mu 1)$ was added to initiate the reaction and the change in relative fluorescence was recorded over $2-5 \mathrm{~min}$ at $37^{\circ}$ using an AmincoBowman spectrophotofluorometer (41) at an excitation wave length of $335 \mathrm{~nm}$, and an emission wave length of $455 \mathrm{~nm}$. Blanks consisted of either substrate and buffer alone or substrate and buffer plus enzyme source heated to $80^{\circ}$ for $10 \mathrm{~min}$. In either case, nonenzymic hydrolysis was negligible for periods up to $2 \mathrm{hr}$. The assay was linear with protein concentration (from $1-150 \mu \mathrm{g} / \mathrm{ml}$ ) and with time for at least $30 \mathrm{~min}$. One unit of LAL activity is defined as $1 \mathrm{nmol}$ substrate hydrolyzed $/ \mathrm{min} / \mathrm{mg}$ protein, by reference to a standard curve for 4-methylumbelliferone (38) fluorescence.

Radioassays. The assay for acid triglyceride lipase activity was carried out according to the method of Sloan and Fredrickson (26) using glyceryl tri[ $\left.1-^{14} \mathrm{C}\right]$ oleate $(42)$, specific activity $55 \mathrm{mCi} / \mathrm{mmol}$. The assay for acid cholesteryl ester hydrolase was carried out according to the method of Takano et al. (27) using cholesteryl-[1${ }^{14} \mathrm{C}$ ]oleate (42), specific activity $21 \mathrm{mCi} / \mathrm{mmol}$, egg yolk lecithin (39), and sodium taurocholate (40). Both reactions were incubated for $2 \mathrm{hr} .{ }^{14} \mathrm{C}$-Labeled free fatty acids were extracted by the method of Schotz et al. (24) and counted in Instagel (43) using a Packard Tri-Carb liquid scintillation counter (43). Quench correction was achieved by the automatic external standards method. Counting efficiency was approximately $85 \%$. Results were expressed as picomoles of free fatty acid liberated per hr per mg protein.

Protein Determination. Protein concentration was measured by the method of Lowry et al. (17).

\section{CELLOGEL ELECTROPHORESIS}

Electrophoresis in Cellogel (44) was carried out using $0.25 \mathrm{M}$ barbital- $\mathrm{HCl}$ buffer, $\mathrm{pH} 8.6$, for $3 \mathrm{hr}$ at $4^{\circ}$ and $250 \mathrm{~V}$ or $0.03 \mathrm{M}$ phosphate- $0.01 \mathrm{M}$ citric acid, $\mathrm{pH} 6.3$, for $3 \mathrm{hr}$ at room temperature and $150 \mathrm{~V}$, using $5-50 \mu \mathrm{l}(1-150 \mu \mathrm{g}$ protein) of enzyme source. Gels were stained for LAL activity using 4-methylumbelliferyl oleate, prepared according to the method of fluorometric assay described above. After prerinsing for $1 \mathrm{~min}$ in $0.2 \mathrm{M}$ acetate buffer, $\mathrm{pH} 4.0$, gels were stained for $5 \mathrm{~min}$. Excess stain was decanted and the gels were incubated at $37^{\circ}$ and viewed periodically under long wave ultraviolet illumination until bands of $\mathrm{LAL}$ appeared.

\section{RESULTS}

\section{OIL RED O STAINING}

Figure 1 demonstrates the massive accumulation of Oil Red O-positive material in WD fibroblasts. There was no such accumulation seen in heterozygote or control cells.

\section{LAL ACTIVITY IN FIBROBLASTS AND LEUKOCYTES}

Table 2 summarizes the LAL activities of fibroblasts, using 4-MUO, triolein (glyceryl trioleate), and cholesteryl oleate as 
substrates. With 4-MUO, both WD and CESD cells had less than $10 \%$ of control levels of LAL activity, and heterozygotes had about $50 \%$. These results compare favorably with those seen using the radioactive substrates. The activities of two lines obtained from cultures of amniotic fluid cells were 12.1 and 10.5 , respectively, using 4-MUO as substrate.

Peripheral leukocytes obtained from 34 laboratory volunteers (19 females, 15 males) showed considerable variation in LAL activity when measured using 4-MUO. The sample mean activity $( \pm \mathrm{SD})$ was $4.0 \pm 1.8$. When blood samples from three individuals were sedimented in Lymphoprep, the lymphocytes contained 19.8 $\pm 2.3 \mathrm{U}$ LAL activity and granulocytes contained $0.8 \pm 0.3 \mathrm{U}$.

Sonication of fibroblasts, amniotic fluid cells, and leukocytes was found to release significantly more LAL activity than did freezing and thawing.

\section{CELLOGEL ELECTROPHORESIS OF LAL}

Figure 2 shows the results of electrophoresis of fibroblast extracts and staining for $\mathrm{LAL}$ using 4-MUO. Lane 3 is a control line, with at least three bands, labeled $A, B$, and $C$. The least anodal band, $\mathrm{A}$, was the most prominent one in controls but was reduced in heterozygotes (lane 2) and was undetectable in both WD and CESD (lanes 1 and 4 , respectively). Band $B$ was present in cells from all individuals tested. Band $C$ was present in some, but not all samples. It could often be detected only when 5-10-fold concentrations of samples were applied to gels. Band $\mathrm{A}$, on the other hand, was never seen in WD and CESD cells, even when highly concentrated (15-fold) samples were applied.

Cultured amniotic fluid cells from normal fetuses showed the same bands, but with reduced intensity, as the normal adult fibroblasts. Leukocytes, and especially lymphocytes (Fig. 3), contained both bands $\mathrm{A}$ and $\mathrm{B}$, but no LAL activity could be seen in granulocytes. Lymphocytes were electrophoretically indistinguishable from normal fibroblasts. Similarly, tissues obtained at autopsy from individuals not affected with WD (liver, spleen, lymph nodes, aorta) showed bands A and B. LAL could not be detected in serum.

\section{DISCUSSION}

Marked deficiency of lysosomal acid lipase in man is associated with considerable clinical variability. Although slightly more activity is measured in CESD cells than in WD cells, this does not readily explain the striking difference in the clinical course of the two diseases. They may result from the same mutation, and some other factor(s) may protect patients with CESD from the profound disease seen in WD. It is of interest to note the occurrence (19) in one family of two siblings with LAL deficiency. One was a child with all the classic features of WD, except for slightly later onset (4 months) and longer survival (death at 14 months), and the other was a young sibling whose first hospital admission was at 12 months. Except for continuing bouts of diarrhea and the appearance of abdominal distention, the child was reported well at 4.5 years.

WD and CESD may be expressions of different mutations at the same or different loci. If so, then WD and CESD cells should readily complement one another when heterokaryons of the two are made by cell fusion $(23,28)$.

Apart from the striking difference in clinical course of the two diseases, other distinctions have been made. Fredrickson et al. (10) have found that the lipolytic activities of both WD and CESD tissues toward most esters were virtually absent but a CESD liver had nearly normal activity towards hexadecanyl-1,2-dioleate, whereas a WD liver had no activity. Assman et al. (1) compared the types of cholesteryl esters stored in WD and CESD tissues and found that WD tissues (including those from patient $A J$ ) had excessive storage of oxygenated steryl esters. This was not seen in the patient $(L M c)$ with CESD.

Despite considerable variation in LAL activity among fibroblasts of the eight healthy control subjects that we tested, we observed no overlap between the normal and heterozygote levels of LAL. All eight cell lines had identical electrophoresis patterns.

Our observation that heterozygotes have about $50 \%$ of control LAL activity is consistent with some published results $(13,19)$ but not with others (20). Heterozygotes for CESD have been shown to have intermediate levels of LAL activity (2).

Electrophoresis of LAL shows absence of band A from both WD and CESD cells and considerably reduced band $A$ in the heterozygotes, when compared with controls. The residual $(<10 \%)$ activity measured in WD and CESD is probably due to the $B$ isozyme. The relationships among bands $A, B$, and $C$ are unclear, although some preliminary results suggest that B differs from $A$ in molecular weight and substrate specificity.

LAL activity in amniotic fluid cells can be measured and its electrophoretic pattern is the same as that seen from cultured skin fibroblasts, allowing the prenatal diagnosis of WD to be made. The successful prenatal diagnosis of WD has been recently reported

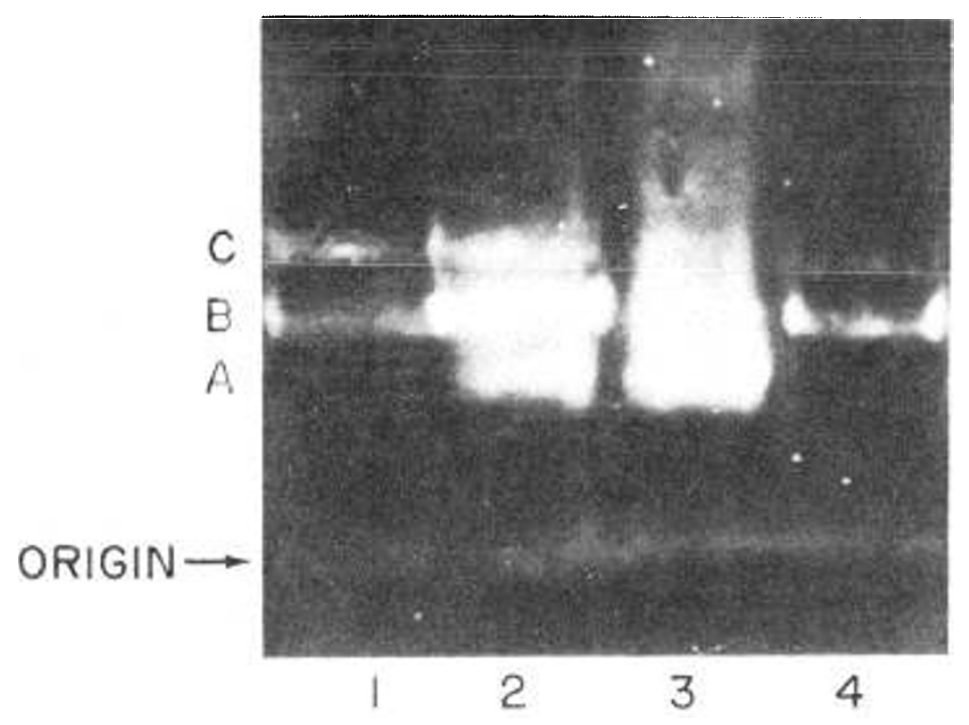

Fig. 2. Cellogel electrophoresis of extracts of cultured fibroblasts and staining with 4-methylumbelliferyl oleate at $\mathrm{pH} 4.0$. Anode at the top. I: Wolman's disease; 2: heterozygote (parent of Wolman's disease patient); 3: normal subject: 4: cholesteryl ester storage disease. 


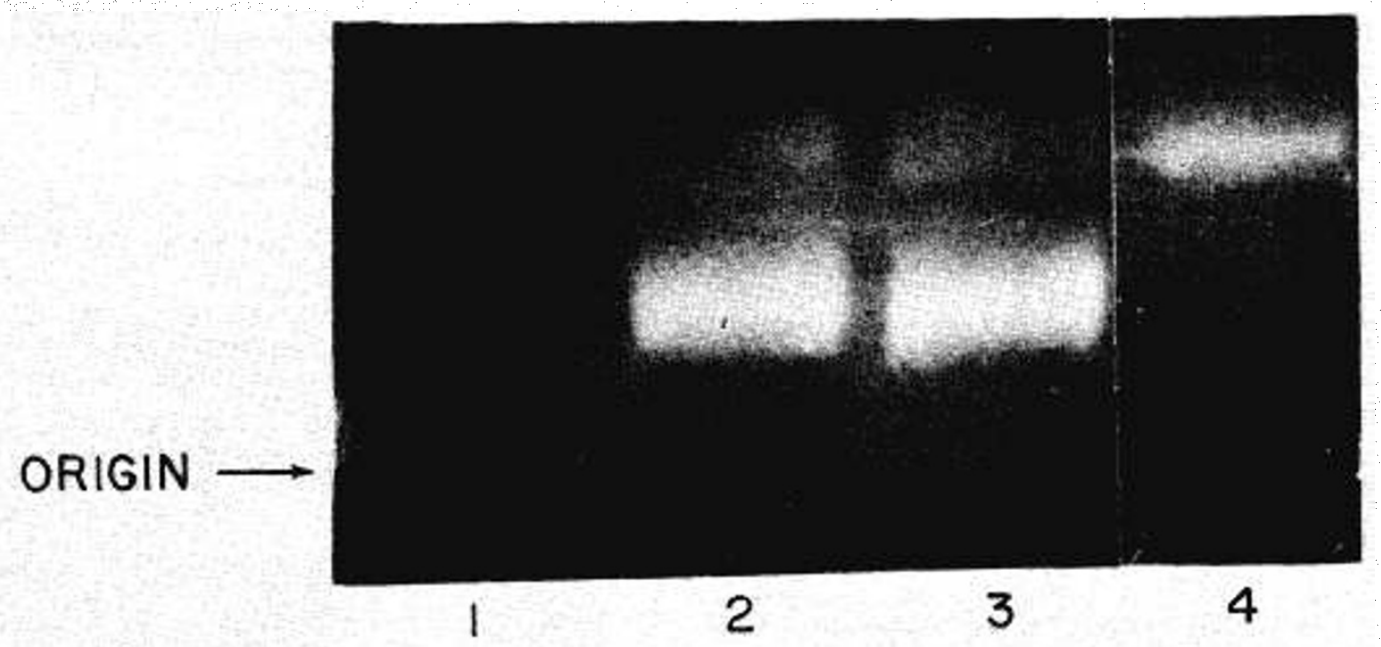

Fig. 3. Cellogel electrophoresis of lysosomal acid lipase in leukocytes and fibroblasts. Anode at the top. 1 : granulocytes; 2: lymphocytes; 3: control fibroblasts; 4: Wolman's disease fibroblasts.

(20), based on the deficiency of LAL in cultured amniotic fluid cells from the affected fetus.

The findings in normal white cells, particularly lymphocytes, of LAL activity and reproducible isozyme patterns by electrophoresis make it possible to survey a population for variants of LAL. WD is a rare disorder, apparently no more prevalent in one ethnic group than another, and therefore screening the general population for WD heterozygotes would be impractical. Nevertheless, the availability of these methods permits the analysis of genetic variation at the LAL locus.

One consequence of genetic variation of LAL is potentially of great importance. During the development of atherosclerosis, cholesteryl esters accumulate within lysosomes of arterial smooth muscle cells $(11,21)$, and DeDuve (8) has suggested that this could result from the relative deficiency of $\mathrm{LAL}$. Indeed, one patient with CESD who died at age 21 of causes apparently unrelated to LAL deficiency showed an extraordinary degree of atherosclerosis for her age (10). Furthermore, all WD patients in whom postmortem examination of the arteries was made showed some degree of fat accumulation $(7,15,16,18,29-31$, and present case). It is possible that genetic variants of LAL can be found with reduced or altered hydrolytic activity toward cholesteryl esters. Individuals with these variants may be at increased risk of developing premature atherosclerosis, especially when challenged by high circulating levels of serum lipids.

The recent work of Brown and Goldstein (5) has defined the metabolic problem present in familial hypercholesterolemia, an inherited disorder known to predispose to premature atherosclerosis. In this condition there is defective synthesis of low density lipoprotein (LDL) receptors indirectly resulting in massive accumulation of intracellular (but not intralysosomal) cholesterol. LAL activity in the fibroblasts from patients who are homozygous or heterozygous for this disorder has been inferred to be normal.

\section{SUMMARY}

Lysosomal acid lipase was measured using 4-methylumbelliferyl oleate in a new fluorometric assay and in published radioassays. Fibroblasts from one patient with WD and one patient with CESD had less than $10 \%$ and heterozygotes for WD had about $50 \%$ of control LAL activity. Both WD and CESD cells showed complete absence of the A isozyme, normally found after electrophoresis of control cells. The same electrophoretic pattern found in control fibroblasts was detected in cultured amniotic fluid cells, peripheral leukocytes, and in tissues obtained at autopsy. These studies suggest that populations can be screened for genetic variants of LAL and such variants may be associated with premature atherosclerosis.

\section{REFERENCES AND NOTES}

1. Assman, G., Fredrickson, D. S., Sloan, H. R., Fales, H. M., and Highet, R. J. Accumulation of oxygenated steryl esters in Wolman's disease. J. Lipid Res. 16: 28 (1975)

2. Beaudet, A. L., Lipson, M. H., Ferry, G. D., and Nichols, B. L.: Acid lipase in cultured fibroblasts: Cholesterol ester storage disease. J. Lab. Clin. Med., 84: 54 (1974).

3. Beratis, N. G., Turner, B. M., Weiss, R., and Hirschhorn, K.: Arylsulfatase B deficiency in Maroteaux-Lamy syndrome: Cellular studies and carrier identification. Pediat. Res., 9: 475 (1975).

4. Böyum, A.: Separation of leucocytes from blood and bone marrow. Scand. J Clin. Lab. Invest., 21(suppl. 97): 7 (1968).

5. Brown, M. S., and Goldstein, J. L.: Receptor-mediated control of cholesterol metabolism. Science, 191: 150 (1976).

6. Cortner, J. A., and Swoboda, E.: Wolman's disease: Prenatal diagnosis: identification of the missing lysosomal acid lipase. Amer. J. Human Genet., 26 23A (1974).

7. Crocker, A. C., Vawter, G. F., Neuhauser, E. B. D., and Rosowsky, A. Wolman's disease: Three new patients with a recently described lipidosis. Pediatrics, 35: 627 (1965).

8. DeDuve, C.: Exploring cells with a centrifuge. Science, 189: 186 (1975).

9. Ferrans, V. J., and Fredrickson, D. S.: The pathology of Tangier disease: A light and electron microscopic study. Amer. J. Pathol., 78: 101 (1975).

10. Fredrickson, D. S., Sloan, H. R., Ferrans, V. J., and Demosky, S. J.: Cholesteryl ester storage disease: A most unusual manifestation of deficiency of two lysosomal enzyme activities. Trans. Ass. Amer. Phys., 85: 109 (1972)

11. Goldfischer, S., Schiller, B., and Wolinsky, H.: Lipid accumulation in smooth muscle cell lysosomes in primate atherosclerosis. Amer. J. Pathol., 78: 497 (1975).

12. Kamalian, N., Dudley, A. W., and Beroukhim, F.: Wolman's disease with jaundice and subarachnoid hemorrhage. Amer. J. Dis. Child., 126: 671 (1973).

13. Kyriakides, E. C., Paul, B., and Balint, J. A.: Lipid accumulation and acid lipase deficiency in fibroblasts from a family with Wolman's disease, and their apparent correction in vitro. J. Lab. Clin. Med., 80: 810 (1972).

14. Lajo, A., Gracia, R., Navarro, M., Nistal, M., and Rabodán, B.: Enfermeded de Wolman en su forma aguda infantil. An. Esp. Pediat. 7: 438 (1974).

15. Leclerc, J. L., Hould, F., Lelievre, M., and Gagne, F.: Maladie de Wolman: Etude anatomo-clinique d'une nouvelle observation avec absence de calcifications radiologiques et macroscopiques des surrenales. Laval Med., 42: 461 (1971).

16. Lowden, J. A., Barson, A. J., and Wentworth, P.: Wolman's disease: A microscopic and biochemical study showing accumulation of ceroid and esterified cholesterol. Can. Med. Ass. J., 102: 402 (1970).

17. Lowry, O. H., Rosebrough, N. J., Farr, A. L., and Randall, R. J.: Protein measurement with the Folin phenol reagent. J. Biol. Chem., 193: 265 (1951).

18. Marshall, W. C., Ockenden, B. G., Fosbrooke, A. S., and Cumings, J. N Wolman's disease: A rare lipidosis with adrenal calcification. Arch. Dis Childhood, 44: 331 (1969).

19. Patrick, A. D., and Lake, B. D.: Wolman's disease. In: H. G. Hers and F. van 
Hoof: Lysosomes and Storage Diseases, p. 453 (Academic Press, New York, 1973).

20. Patrick, A. D., Willcox, P., Stephens, R., and Kenyon, V. G.: Prenatal diagnosis of Wolman's disease. J. Med. Genet., 13: 49 (1976).

21. Peters, T. J., Takano, T., and DeDuve, C.: In: R. Porter and J. Knight: Atherogenesis, Initiating Factors, Ciba Foundation Symposium 12, p. 197 (Elsevier, Amsterdam, 1973).

22. Raafat, R., Hashemian, M. P., and Abrishami, M. A.: Wolman's disease: Report of two new cases with a review of the literature. Amer. J. Clin. Pathol., 59: 490 (1973).

23. Rattazzi, M. C., Brown, J. A., Davidson, R. G., and Shows, T. B.: Tay-Sachs and Sandhoff-Jatzkewitz diseases: Complementation of $\beta$-hexosaminidase deficiency by somatic cell hybridization. Amer. J. Hum. Genet., 26: 71 A (1974).

24. Schotz, M. C., Garfinkel, A. S., Huebotter, R. J., and Stewart, J. E.: A rapid assay for lipoprotein lipase. J. Lipid Res., 11: 68 (1970).

25. Sloan, H. R., and Fredrickson, D. S.: Rare familial diseases with neutral lipid storage; Wolman's disease, cholesteryl ester storage disease and cerebrotendinous xanthomatosis. In: J. B. Stanbury, J. B. Wyngaarden, and D. S. Frederickson: The Metabolic Basis of Inherited Disease, Ed. 3, p. 808 (McGrawHill, New York, 1972).

26. Sloan, H. R., and Fredrickson, D. S.: Enzyme deficiency in cholesteryl ester storage disease. J. Clin. Invest., 5I: 1923 (1972)

27. Takano, T., Black, W. J., Peters, T. J., and DeDuve, C.: Assay, kinetics and lysosomal localization of an acid cholesteryl esterase in rabbit aortic smooth muscle cells. J. Biol. Chem., 249: 6732 (1974).

28. Thomas, G. H., Taylor, H. A., Miller, C. S., Axelman, J., and Migeon, B. R. Genetic complementation after fusion of Tay-Sachs and Sandhoff cells. Nature, 250: 580 (1974).

29. Uno, Y., Taniguchi, A., and Tanaka, E.: Histochemical studies in Wolman's disease-Report of an autopsy case accompanied with a large amount of milky ascites. Acta Path. Jap., 23: 779 (1973).

30. Wallis, K., Gross, M., Kohn, R., and Zaidman, J.: A case of Wolman's disease. Helv. Paediat. Acta, 26: 98 (1971)

31. Wolf, H., Hug, G., Michaelis, R., and Nolte, K.: Seltene, angeborene Erkrankung mit Cholesterinester-Speicherung in der Leber. Helv. Paediat. Acta, 29: 105 (1974).

32. Wolman, M., Sterk, V. V., Gatt, S., and Frankel, M.: Primary familial xanthomatosis with involvement and calcification of the adrenals. Pediatrics,
28: 274 (1961)

33. Lysosomal acid lipase is the term we have chosen to denote the enzyme which is deficient in WD and CESD. It has been variously called acid lipase $(2,13)$, acid esterase (19) and the activities measured as acid cholesteryl ester hydrolase and acid triglyceride lipase $(10,26)$.

34. Grand Island Biological Co., Grand Island, N. Y.

35. Bellco Glass, Inc., Vineland, N. J.

36. Heat Systems/Ultrasonics, Plainview, N. Y.

37. Gallard-Schlesinger, Carle Place, N. Y.

38. Research Products International, Elk Grove Village, III.

39. Supelco, Inc., Bellefonte, Pa.

40. Sigma Chemicals, St. Louis, Mo

41. American Instrument Company, Silver Springs, Md.

42. Amersham-Searle Corp., Arlington Heights, III.

43. Packard Instrument Co., Downers Grove, Ill.

44. Kalex Scientific, Manhasset, N. Y.

45. This work was supported by General Research Support Grant, National Institutes of Health no. RR-05493; the National Institutes of Health, Maternal and Child Health Service Grant no. MCT-00417; and National Institutes of Health, National Institute of Arthritis, Metabolism and Digestive Diseases Grant no. AM-06872.

46. We thank Ms. C. Kavai, Ms. B. Marotta, and Mr. J. El-Khoury for their valuable technical assistance, Drs. Fredrickson and Sloan for the lipid and enzyme analyses of the tissues of our patient, as well as for their kindness in giving us cells from their patient with CESD, and Drs. Harry Harris, William Mellman, and Stanton Segal for reviewing the manuscript.

47. These studies were performed with the informed consent of the subjects, or in the case of children, with the informed consent of their parents.

48. The present address of Drs. J. A. Cortner and P. M. Coates is: Joseph Stokes, Jr. Research Institute, Children's Hospital of Philadelphia, 34th and Civic Center Blvd., Philadelphia, Pa. 19104.

49. The present address of Dr. E. Swoboda is: E. J. Meyer Memorial Hospital, Buffalo, N. Y. 14215.

50. Requests for reprints should be addressed to: J. A. Cortner, M.D., Physician-inChief, Children's Hospital of Philadelphia, 34th and Civic Center Blvd., Philadelphia, Pa. 19104 (USA).

51. Accepted for publication May 21, 1976.
Ductus arteriosus

fetus

foramen ovale lung

positive end expiratory pressure

\title{
Positive End Expiratory Pressure (PEEP) and Right to Left Shunting in Immature Goats
}

\author{
EDMUND A. EGAN ${ }^{(27)}$ AND JACK R. HESSLER
}

Departments of Pediatrics and Comparative Medicine, University of Florida College of Medicine, Gainesville,

Florida, USA

\section{Extract}

Immature fetal goats were exteriorized by caesarean section and catheters were placed in a pulmonary vein (PV), carotid artery (CA), femoral artery (FA), and the main pulmonary artery (PA). The goats were ventilated at 7.5 and $15 \mathrm{~cm} \mathrm{H}_{2} \mathrm{O}$ positive end expiratory pressure (PEEP) between control periods at 0 PEEP. Right to left shunting $\left(Q_{s} / Q_{t}\right)$ was calculated for three anatomic sites: lung, foramen ovale, and ductus arteriosus, and for two summation shunts: preductal and total. Total $Q_{s} / Q_{t}$ increased in 8 of 14 animals at $7.5 \mathrm{~cm} \mathrm{H}_{2} \mathrm{O}$ PEEP and in 7 of 12 animals at $15 \mathrm{~cm}$ $\mathrm{H}_{2} \mathrm{O}$ PEEP. Intrapulmonary shunting increased in only one experiment. The increase in total $Q_{8} / Q_{t}$ resulted from elevated extrapulmonary shunting, always including the ductus arteriosus. The variation in response to PEEP was from animal to animal and not from one level to another within one animal. Changes in total $Q_{s} / Q_{t}$ on PEEP did not correlate with the size of control $Q_{\mathrm{z}} / \mathrm{Q}_{\mathrm{t}}$ at any site.

\section{Speculation}

PEEP can simultaneously improve oxygenation of pulmonary venous blood and lower systemic oxygen content in newborn mammals with lung disease. This suggests that PEEP has important physiologic effects on distribution of the neonatal cardiopulmonary circulation. Future quantitative definitions of these relationships may improve the management of hypoxemia neonatal respiratory failure.

Positive end expiratory pressure used with positive pressure 